\title{
Onset of obesity in a 36 year birth cohort study
}

\author{
FIONA E M BRADDON, BRYAN RODGERS, MICHAEL E J WADSWORTH, \\ JOHN M C DAVIES
}

\begin{abstract}
A large national cohort of children studied from birth to 36 years was used to test the predictive value of childhood obesity for obesity in adult life. Only $21 \%$ (39) of obese 36 year olds had been obese at age 11 years, and even when associated social factors were taken into account the correctly predicted percentage was much lower than the prediction rate achieved using body mass data from age 26 years. The comparatively poor predictive value of childhood obesity and the associations of adult obesity with educational achievements and socioeconomic circumstances of family of origin emphasise the need for encouraging good nutritional and exercise habits rather than placing undue emphasis on the control of childhood obesity.
\end{abstract}

\section{Introduction}

Obesity and overweight have been implicated in the clinical course of many chronic conditions of middle and old age. ${ }^{1}$ The prevalence of obesity and overweight is rising and becoming more common at progressively younger ages. ${ }^{2}{ }^{3}$ In men obesity acquired in their $20 \mathrm{~s}$ has been found to be associated with increased risk of premature death from coronary disease and stroke.$^{3.5}$ Little is known, however, about the clinical course of obesity. Cross sectional studies ${ }^{6.9}$ have shown that obesity increases with age throughout the adult years, but such "survey data are, in effect, a snapshot of the population at the time of fieldwork, and the different averages in each age group may be due to different patterns of nutrition, upbringing, and

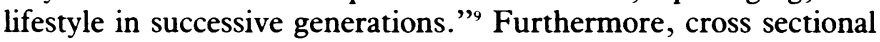

\footnotetext{
Medical Research Council National Survey of Health and Development, Department of Epidemiology and Community Medicine, University of Bristol

FIONA E M BRADDON, DIPDIET, BA, research assistant

BRYAN RODGERS, MA, MSC, research associate

MICHAEL E J WADSWORTH, MPHIL, PHD, senior research fellow

JOHN M C DAVIES, BSC, research assistant

Correspondence to: Mrs Braddon.
}

studies can say nothing of the degree of normative change that takes place with age.

There have been few longitudinal studies of obesity spanning both childhood and adult years. Follow up studies of obese children, reviewed by Mullins, have shown that many such people are still obese or overweight as adults. ${ }^{10}$ Prospective studies of more representative samples support the view that overweight and obese children are more likely to be obese in later life than their peers of normal weight, although the predictive value of childhood information decreases with time. ${ }^{1119}$ There also appears, however, to be no history of childhood obesity for a high proportion of obese adults. ${ }^{16-19}$ One such study reported the prevalence of overweight at several ages between 6 and 26 years and the correlations between relative weights at those ages from a follow up of the 1946 British birth cohort. ${ }^{18}$ In our study we extended previous work to include the study of obesity in the same cohort at 36 years old. We describe, firstly, the change in prevalence of obesity with age and, secondly, individual differences in the course and pattern of obesity

\section{Methods}

The Medical Research Council National Survey of Health and Development is a study of children born in one week in March 1946 in all parts of England, Wales, and Scotland. The study began in that year and has since continued to investigate many aspects of the lives of a sample of those born in the study week. The follow up sample comprises all legitimate, single births to wives of non-manual and agricultural workers and one in four of all other legitimate single births-a total of 5362 individuals. This stratified sampling may be compensated for by a statistical weighting procedure.

Contacts during the infant and school years were made at intervals of two years or less and in adult life at longer intervals. The data collected have always been as widely representative as possible of medical, educational, occupational, social, and psychological concerns. A fuller description of the study and of the data collected is given elsewhere..$^{20}$

Losses have occurred as a result of death and emigration, but from comparisons with published data on rates of illness, criminality, divorce, hospital admissions, and census data the sample appears still to be representative of people of this age who were born in Great Britain. At the age of 36 years 3754 of the 5362 members of the study population were contacted, and of these, 3322 were successfully interviewed in their homes by specially trained nurses. This interview included a physical examination at which height without shoes was measured in centimetres to the nearest 0.5 $\mathrm{cm}$ below and weight in light indoor clothing was measured in $\mathrm{kg}$ to the nearest $0.5 \mathrm{~kg}$ below. Weight was adjusted by subtracting $1.0 \mathrm{~kg}$ for men and $0.5 \mathrm{~kg}$ for women as a correction for clothes worn. These measurements were 
obtained for 3280 people, $99 \%$ of those visited. Of these, 31 women were excluded from analysis as they were pregnant at the time of the interview. Heights and weights had been measured previously by school doctors or nurses around the time of 7 th and 11 th birthdays and again at the age of 14 (median 14 years 6 months) and had been self reported at 20 and 26. The accuracy of self reported height and weight data was investigated in a subsample and reported by Stark et al, who concluded that "self-reported heights and weights might have led to an underestimate of the prevalence of overweight at 20 and 26 years" but that systematic adjustment of values was not justified. ${ }^{18}$ Stewart gives an indication of biases that may result from the use of self reported data. ${ }^{21}$

At younger ages $(7,11$, and 14 years) an index of relative weight was used to express measures of weight for height-that is, weight expressed as a percentage of a standard weight, calculated for specified height, age, and sex. ${ }^{22}{ }^{23}$ This study's sample size was sufficiently large and representative to allow the estimation of standard weights from its own data. In the adult years $(20,26$, and 36 years) body mass index was used, which is a fixed rather than age specific standard. This is appropriate when change of height with age is small. Support for the use of the body mass index is given by Garrow, ${ }^{2}$ and Ashwell et al have shown its high correlation with total body fat. ${ }^{24}$

Cut off points were used to define underweight, normal weight, overweight, and obesity. For the index of relative weight the ranges were underweight $<90$; normal $90-110$; overweight 111-130; obesity $>130 ; 100$ was the standard weight and obesity was roughly $20 \%$ above the top of the normal range. Unlike the index of relative weight, body mass index is calculated in an identical manner for men and women. Durnin and Womersley, however, have shown that for the same body mass index women have a higher percentage of body fat than men. ${ }^{25}$ In this study we used different body mass index cut off points for men and women to establish continuity with the earlier measures in the index of relative weight. For men the body mass index cut off points $20 \cdot 0,25 \cdot 0$, and $30 \cdot 0$ were as suggested by Bray. ${ }^{26}$ Corresponding cut off points for women were derived from the comparisons of the index of relative weight and body mass index distributions at age 20 , these being $19 \cdot 4,24 \cdot 3$, and $29 \cdot 1$.

\begin{tabular}{|c|c|c|c|c|c|c|c|c|}
\hline \multirow{2}{*}{$\begin{array}{l}\text { Weight } \\
\text { category }\end{array}$} & \multirow{2}{*}{$\begin{array}{c}\text { Relative } \\
\text { weight } \\
\text { index }\end{array}$} & \multirow{2}{*}{$\begin{array}{l}\text { Body } \\
\text { mass } \\
\text { index }\end{array}$} & \multicolumn{6}{|c|}{ Age (years) } \\
\hline & & & 7 & 11 & 14 & 20 & 26 & 36 \\
\hline \multicolumn{9}{|c|}{ Men } \\
\hline $\begin{array}{l}\text { Underweight } \\
\text { Normal } \\
\text { Overweight } \\
\text { Obese }\end{array}$ & $\begin{array}{c}<90 \\
90-110 \\
111-130 \\
>130\end{array}$ & $\begin{array}{c}<20 \cdot 0 \\
20 \cdot 0-24 \cdot 9 \\
25 \cdot 0-29 \cdot 9 \\
>29 \cdot 9\end{array}$ & $\begin{array}{r}7 \cdot 5 \\
82 \cdot 8 \\
9 \cdot 2 \\
0 \cdot 5\end{array}$ & $\begin{array}{r}12 \cdot 8 \\
71 \cdot 6 \\
12.5 \\
3.1\end{array}$ & $\begin{array}{r}14 \cdot 2 \\
68 \cdot 9 \\
14 \cdot 5 \\
2 \cdot 3\end{array}$ & $\begin{array}{r}14 \cdot 4 \\
73 \cdot 0 \\
11 \cdot 6 \\
1.0\end{array}$ & $\begin{array}{r}9 \cdot 2 \\
67 \cdot 2 \\
21 \cdot 3 \\
2 \cdot 3\end{array}$ & $\begin{array}{r}6 \cdot 4 \\
50 \cdot 3 \\
38 \cdot 0 \\
5 \cdot 3\end{array}$ \\
\hline No of men $(=100 \%)$ & & & $\begin{array}{c}2057 \\
\text { Wom }\end{array}$ & 2050 & 1881 & 1829 & 1822 & 1630 \\
\hline $\begin{array}{l}\text { Underweight } \\
\text { Normal } \\
\text { Overweight } \\
\text { Obese }\end{array}$ & $\begin{array}{c}<90 \\
90-110 \\
111-130 \\
>130\end{array}$ & $\begin{array}{c}<19 \cdot 4 \\
19 \cdot 4-24 \cdot 2 \\
24 \cdot 3 \cdot 29 \cdot 1 \\
>29 \cdot 1\end{array}$ & $\begin{array}{r}11 \cdot 5 \\
74.9 \\
12.4 \\
1.2\end{array}$ & $\begin{array}{r}19 \cdot 8 \\
61 \cdot 0 \\
14.3 \\
4.9\end{array}$ & $\begin{array}{r}21 \cdot 0 \\
58 \cdot 4 \\
16 \cdot 6 \\
4 \cdot 0\end{array}$ & $\begin{array}{r}18 \cdot 9 \\
65 \cdot 4 \\
13 \cdot 3 \\
2 \cdot 5\end{array}$ & $\begin{array}{r}13 \cdot 7 \\
64 \cdot 7 \\
17 \cdot 9 \\
3 \cdot 7\end{array}$ & $\begin{array}{r}8 \cdot 2 \\
59 \cdot 2 \\
24 \cdot 2 \\
8 \cdot 4\end{array}$ \\
\hline No of women $(=100 \%)$ & & & 1920 & 1887 & 1700 & 1735 & 1782 & 1619 \\
\hline
\end{tabular}

TABLE II-Correlation between measures of weight for height ${ }^{\star}$ at several ages

\begin{tabular}{lcccccc}
\hline & & \multicolumn{5}{c}{ Age (years) } \\
\cline { 3 - 7 } & $\begin{array}{c}\text { Age } \\
\text { (years) }\end{array}$ & 11 & 14 & 20 & 26 & 36 \\
\hline \multirow{2}{*}{ Men } & 7 & 0.62 & 0.52 & 0.41 & 0.33 & 0.28 \\
& 11 & & 0.73 & 0.54 & 0.46 & 0.45 \\
& 14 & & & 0.57 & 0.52 & 0.46 \\
& 20 & & & & 0.77 & 0.64 \\
& 26 & & & & & 0.75 \\
\multirow{4}{*}{ Women } & 7 & 0.69 & 0.59 & 0.47 & 0.40 & 0.40 \\
& 11 & & 0.74 & 0.58 & 0.51 & 0.51 \\
& 14 & & & 0.71 & 0.64 & 0.60 \\
& 20 & & & & 0.75 & 0.66 \\
& 26 & & & & & 0.76 \\
& & & & & &
\end{tabular}

^Relative weight index at ages 7,11 , and 14; body mass index at ages 20,26 , and 36 .

TABLE III-Index of weight for height at earlier ages for men and women obese at 36 years

\begin{tabular}{|c|c|c|c|c|c|c|}
\hline \multirow{2}{*}{$\begin{array}{l}\text { Weight } \\
\text { category` }\end{array}$} & \multicolumn{6}{|c|}{$\%$ In each weight category at age: } \\
\hline & 7 & 11 & 14 & 20 & 26 & 36 \\
\hline \multicolumn{7}{|c|}{ Men } \\
\hline Underweight & $1 \cdot 3$ & $1 \cdot 3$ & 0.4 & 0 & 0 & \\
\hline Normal & $70 \cdot 1$ & $37 \cdot 2$ & $40 \cdot 3$ & $32 \cdot 8$ & $8 \cdot 2$ & \\
\hline Overweight & $26 \cdot 0$ & $51 \cdot 3$ & $44 \cdot 4$ & $56 \cdot 3$ & $61 \cdot 6$ & \\
\hline Obese & $2 \cdot 6$ & $10 \cdot 3$ & 13.9 & 10.9 & $30 \cdot 1$ & 100 \\
\hline No of ment & 77 & $\begin{array}{l}78 \\
\text { Women }\end{array}$ & 72 & 64 & 73 & 86 \\
\hline Underweight & 3.7 & $2 \cdot 9$ & $1 \cdot 0$ & 0.0 & 0.0 & \\
\hline Normal & 59.8 & $43 \cdot 3$ & $31 \cdot 7$ & $31 \cdot 4$ & $17 \cdot 0$ & \\
\hline Overweight & $29 \cdot 0$ & $24 \cdot 0$ & $35 \cdot 6$ & $43 \cdot 1$ & $49 \cdot 1$ & \\
\hline Obese & $7 \cdot 5$ & $29 \cdot 8$ & $31 \cdot 7$ & $25 \cdot 5$ & $33 \cdot 9$ & 100 \\
\hline No of woment & 107 & 104 & 104 & 102 & 112 & 135 \\
\hline
\end{tabular}

*Categories are based on relative weight index at ages 7,11 , and 14 and on body mass index at ages 20,26 , and 36 .

†Earlier totals vary because of compliance.

\section{Results}

\section{PREVALENCE OF OBESITY}

The prevalence of obesity in men and women varied with age, reaching a childhood and adolescent peak at age 11 before falling to the age of 20 , and subsequently rising to a much higher prevalence at 36 years (table I). At all ages studied there were proportionately more obese women than men, and proportionately more underweight women than men. These findings are similar to those of a national cross sectional study. ${ }^{9}$

The prevalence of overweight, as compared with obese, people at each age had, however, a different pattern (table I). During childhood and adolescence (at 7, 11, and 14 years) there was a rising trend in both sexes, and the prevalence of overweight girls was greater than that of overweight boys. Prevalence apparently dropped in both sexes by age of 20 , but this fall was rather artificial because, although the index of relative weight and body mass index at this age were highly correlated $(r=0.99)$, the thresholds varied slightly. After the age of 20 prevalence rose sharply, with a higher prevalence of overweight men than women at both 26 years and 36 years. These data were then used to examine the earlier weight for height of those obese at 36 years and to describe some of the personal characteristics of those obese at this age.

\section{CORRELATION BETWEEN MEASURES OF WEIGHT FOR HEIGHT FROM 7 TO 36 YEARS}

The strength of association between weight for height measures at different ages is shown in table II by Pearson correlation coefficients. Correlations declined with longer time intervals, and there was an evident pattern in both sexes of greater stability with increasing age. The strengthening association with adult measures also seemed to occur earlier in girls, particularly between 11 and 14 years, than in boys, where the more notable increase in correlation coefficients was between 14 and 20 years.

\section{EARLIER WEIGHT FOR HEIGHT OF THOSE OBESE AT 36 YEARS}

Table III shows that among men obese at age $36,51 \cdot 3 \%(40)$ were overweight but only $10 \cdot 3 \%(8)$ had been obese at age 11 ; but $91 \cdot 7 \%(67)$ were 
above the normal weight range by age 26 . Of the women obese at age 36 years, only $24 \cdot 0 \%(25)$ were overweight and $29 \cdot 8 \%$ (31) were obese at age 11 . By age 26, 83\% (93) were above normal weight.

\section{PERSONAL CHARACTERISTICS OF OBESE PEOPLE}

Social class-Childhood social circumstances were examined with an indicator of parents' social class and education, ${ }^{27}$ called social group, and this was found to be strongly associated with cohort members' body mass at the age of 36 years. Men and women who in childhood had lived in non-manual class homes were significantly more likely to be in the categories of normal or underweight body mass at 36 years than others, and those from manual homes were more inclined to be overweight or obese, as seen in table IV. obese and $28 \cdot 7 \%$ (183) overweight in those with highest qualifications $\left(\chi^{2}=24 \cdot 38,6 \mathrm{df}, \mathrm{p}<0.001\right)$; and among women $12 \cdot 4 \%(74)$ of those with no qualifications were obese and $26 \cdot 8 \%$ ( 160$)$ overweight, compared with $2 \cdot 2 \%$ (9) obese and $18.0 \%$ (74) overweight in those with the highest qualifications $\left(\chi^{2}=60.58,6 \mathrm{df}, \mathrm{p}<0.001\right)$.

Marital status-Women who had never been married were most likely to be obese; $15.9 \%$ (13) were obese compared with only $7.4 \%(102)$ of currently married women, and $6.9 \%$ (7) of women who had ever been married and were now living alone. Mean body mass index scores in men did not vary with marital status.

Parity-Of the women who had had only one or two pregnancies, $6 \cdot 1 \%$ (58) were obese, whereas $10 \cdot 5 \%(47)$ of those who had had three or more pregnancies were obese. The comparatively high prevalence of obesity among nulliparous women $(9 \cdot 7 \%(21))$ reflected the trend in this cohort for

\begin{tabular}{|c|c|c|c|c|c|}
\hline $\begin{array}{c}\text { Parental } \\
\text { social class }\end{array}$ & $\begin{array}{c}\text { Underweight } \\
(\%)\end{array}$ & $\underset{(\%)}{\text { Normal }}$ & $\begin{array}{c}\text { Overweight } \\
(\%)\end{array}$ & $\begin{array}{c}\text { Obese } \\
(\%)\end{array}$ & $\begin{array}{l}\text { Total } \\
\text { (No) }\end{array}$ \\
\hline \multicolumn{6}{|l|}{ Men: } \\
\hline Non-manual & $7 \cdot 2$ & $59 \cdot 8$ & $28 \cdot 1$ & $4 \cdot 9$ & 697 \\
\hline Manual & $6 \cdot 3$ & $47 \cdot 4$ & $40 \cdot 7$ & $5 \cdot 6$ & 934 \\
\hline \multicolumn{6}{|l|}{ Women: } \\
\hline Non-manual & $12 \cdot 6$ & $66 \cdot 3$ & $17 \cdot 1$ & $4 \cdot 0$ & 667 \\
\hline Manual & 6.9 & $57 \cdot 0$ & $25 \cdot 6$ & $10 \cdot 4$ & 952 \\
\hline
\end{tabular}

Men $\chi^{2}=30 \cdot 28,3 \mathrm{df}, \mathrm{p}<0 \cdot 001$. Women $\chi^{2}=52 \cdot 32,3 \mathrm{df}, \mathrm{p}<0 \cdot 001$.

TABLE V-Distribution of obese subjects at 36 years by social class and sex

\begin{tabular}{ccc}
\hline Social class & $\begin{array}{c}\text { Men } \\
\%(\mathrm{No})\end{array}$ & $\begin{array}{c}\text { Women } \\
\%(\mathrm{No})\end{array}$ \\
\hline I & $4 \cdot 2(167)$ & $7 \cdot 1(14)$ \\
II & $4 \cdot 8(558)$ & $3 \cdot 4(294)$ \\
III Non-manual & $3 \cdot 1(163)$ & $5 \cdot 2(383)$ \\
III Manual & $5 \cdot 9(456)$ & $10 \cdot 1(69)$ \\
IV & $5 \cdot 6(142)$ & $8 \cdot 8(182)$ \\
V & $9 \cdot 5(21)$ & $20 \cdot 6(63)$ \\
Not employed & $8 \cdot 7(104)$ & $9 \cdot 3(599)$ \\
Unknown social class & $5 \cdot 0(20)$ & $20 \cdot 0(15)$ \\
& $\mathrm{n}=1631$ & $\mathrm{n}=1619$ \\
\hline
\end{tabular}

single women to be obese; nulliparous women who had been or who were married were less likely to be obese $(6 \cdot 4 \%(9))$. Although obesity rose with increasing parity, parous women with moderate or high educational achievements showed lower prevalence $(1.5 \%(6)$ were obese) than parous women with no qualifications $(12.9 \%(70)$ obese). The trend towards weight gain with increasing parity was significant $(p<0.05)$ whatever the level of education achieved.

Current smoking habits-Current smoking habits were not associated with obesity at 36 , and in fact a similar percentage of smokers $(6.0 \%(65))$ and non-smokers $(6 \cdot 8 \%(148))$ were obese. The number of cigarettes smoked was not associated with smokers' body mass index.

Birth weight-Up to the age of 14 overweight or obesity in boys and girls was significantly more prevalent in those of higher birth weight, and this has been discussed at greater length elsewhere. ${ }^{28}$ By the age of 36 men, but not

TABLE VI-Factors associated with body mass index at age 36 in men

\begin{tabular}{|c|c|c|c|c|c|}
\hline Variables & No & $\begin{array}{l}\text { Unadjusted } \\
\text { change }\end{array}$ & $\begin{array}{l}\text { Adjusted } \\
\text { change }\end{array}$ & $\begin{array}{c}F \\
\text { to omit }\end{array}$ & $\mathrm{p}$ Value \\
\hline $\begin{array}{l}\text { Relative weight index at } 11 \text { (71-174) } \\
\text { Education: }\end{array}$ & 1231 & $\times 0.12$ & $\times 0.12$ & $340 \cdot 58$ & $<0.001$ \\
\hline $\begin{array}{l}\text { None or up to O level } \\
\text { Post O level }\end{array}$ & $\begin{array}{l}705 \\
526\end{array}$ & $\begin{array}{r}0.37 \\
-0.50\end{array}$ & $\begin{array}{r}0 \cdot 22 \\
-0 \cdot 30\end{array}$ & $7 \cdot 19$ & $<0.01$ \\
\hline $\begin{array}{l}\text { Social group in childhood: } \\
\text { Upper non-manual } \\
\text { Lower non-manual } \\
\text { Upper manual } \\
\text { Lower manual }\end{array}$ & $\begin{array}{l}137 \\
422 \\
214 \\
458\end{array}$ & $\begin{array}{r}-0.77 \\
-0.37 \\
0.29 \\
0.44\end{array}$ & $\begin{array}{r}-0.50 \\
-0.18 \\
0.12 \\
0.29\end{array}$ & $3 \cdot 22$ & $<0.05$ \\
\hline $\begin{array}{l}\text { Body mass index at } 26(13.5-36.9) \\
\text { Education: }\end{array}$ & 1095 & $\times 0.09$ & $\times 0.09$ & $1645 \cdot 00$ & $<0.001$ \\
\hline $\begin{array}{l}\text { None or up to O level } \\
\text { After O level }\end{array}$ & $\begin{array}{l}610 \\
485\end{array}$ & $\begin{array}{r}0.41 \\
-0.51\end{array}$ & $\begin{array}{r}0.17 \\
-0.21\end{array}$ & $7 \cdot 01$ & $<0.01$ \\
\hline
\end{tabular}

Table $\mathrm{V}$ shows that obesity was also associated with adult social class, with higher rates of obesity in the lower social classes for both men and women. A change in social class in adult life relative to that of the families of origin was important in women but not in men. The prevalence of obesity at 36 years among gainfully employed women who rose from manual families of origin to non-manual classes in their own adult life was significantly lower (13, $4.7 \%$ ) than that among women who remained in the manual social classes $(22,11 \cdot 2 \%)$. Women who changed social class tended to show the prevalence of obesity of the class they joined.

Educational achievement-In both sexes body mass index was significantly associated with educational achievement, and the highest prevalence of obesity was found in the least qualified. Among men with no qualifications $6.8 \%(40)$ were obese and $41 \cdot 8 \%(244)$ overweight, compared with $4 \cdot 7 \%(30)$ women, who were obese or overweight had been significantly heavier babies than those of normal weight $(F=12 \cdot 29, p<0 \cdot 001)$.

\section{COMBINED EFFECTS OF FACTORS}

Data on earlier weight for height and on social factors correlated with adult obesity were used in analyses of covariance to assess their relative predictive power and independent association with body mass index at age 36. Firstly, relative weight data were taken from the time when prevalence of obesity was greatest in childhood-that is, 11 years-and secondly, body mass index from age 26 was used. The indices of weight for height were used as continuous measures in these analyses. 
Table VI shows that for men's body mass at age 36 the most powerfully associated factor in both analyses was the index of weight for height, but achieved educational level was also of independent significance. Social group of parents made a contribution only in conjunction with the index of relative weight at 11 years. No other factors were significant.

For women too indices of weight for height were most strongly associated with body mass at 36 years, and achieved educational level was also of independent significance (table VII). In addition, social group in childhood was significant in both analyses, whereas parity made an independent contribution only in conjunction with the index of relative weight at 11
Overall, the predictive value of weight for height measures improved steadily with increasing age, with an acceleration, but not a dramatic one, around puberty. This pattern of increasing normative stability held for the adult years even though the prevalence of obesity and overweight increased rapidly.

The additional independent association of childhood social circumstances with adult obesity and overweight has not been previously reported. The magnitude of influence of social factors was rather small, consistent with the findings of Rona and Morris. ${ }^{29}$

\begin{tabular}{|c|c|c|c|c|c|}
\hline Variables & No & $\begin{array}{l}\text { Unadjusted } \\
\text { change }\end{array}$ & $\begin{array}{l}\text { Adjusted } \\
\text { change }\end{array}$ & $\begin{array}{c}F \\
\text { to omit }\end{array}$ & p Value \\
\hline $\begin{array}{l}\text { Relative weight index at } 11 \text { (65-182) } \\
\text { Education: }\end{array}$ & 1307 & $\times 0.15$ & $\times 0.15$ & $542 \cdot 54$ & $<0.001$ \\
\hline $\begin{array}{l}\text { None or up to O level } \\
\text { After O level }\end{array}$ & $\begin{array}{l}496 \\
811\end{array}$ & $\begin{array}{r}0.85 \\
-0.52\end{array}$ & $\begin{array}{r}0.48 \\
-0.30\end{array}$ & $13 \cdot 19$ & $<0.001$ \\
\hline $\begin{array}{l}\text { Social group in childhood: } \\
\text { Non-manual } \\
\text { Manual }\end{array}$ & $\begin{array}{l}545 \\
762\end{array}$ & $\begin{array}{r}-0.81 \\
0.58\end{array}$ & $\begin{array}{r}-0.36 \\
0.26\end{array}$ & $9 \cdot 06$ & $<0.005$ \\
\hline $\begin{array}{l}\text { Parity: } \\
\text { No children } \\
1 \text { or } 2 \text { children } \\
3 \text { or more children }\end{array}$ & $\begin{array}{l}170 \\
773 \\
364\end{array}$ & $\begin{array}{r}0.32 \\
-0.36 \\
0.62\end{array}$ & $\begin{array}{r}0.00 \\
-0.29 \\
0.62\end{array}$ & $9 \cdot 15$ & $<0.001$ \\
\hline $\begin{array}{l}\text { Marital status: } \\
\text { Single } \\
\text { Ever married }\end{array}$ & $\begin{array}{r}62 \\
1245\end{array}$ & $\begin{array}{r}0.79 \\
-0.04\end{array}$ & $\begin{array}{r}0.89 \\
-0.04\end{array}$ & $3 \cdot 37$ & $0.06^{\star}$ \\
\hline $\begin{array}{l}\text { Body mass index at } 26(15 \cdot 2-50 \cdot 3) \\
\text { Education: }\end{array}$ & 1385 & $\times 0.09$ & $\times 0.09$ & 1838.97 & $<0.001$ \\
\hline $\begin{array}{l}\text { None or up to O level } \\
\text { Post O level }\end{array}$ & $\begin{array}{l}520 \\
865\end{array}$ & $\begin{array}{r}0.94 \\
-0.57\end{array}$ & $\begin{array}{r}0.27 \\
-0.16\end{array}$ & 6.96 & $<0.01$ \\
\hline $\begin{array}{l}\text { Social group in childhood: } \\
\text { Non-manual } \\
\text { Manual }\end{array}$ & $\begin{array}{l}582 \\
803\end{array}$ & $\begin{array}{r}-0.86 \\
0.62\end{array}$ & $\begin{array}{r}-0.25 \\
0.18\end{array}$ & $7 \cdot 20$ & $<0.01$ \\
\hline $\begin{array}{l}\text { Social class in adulthood: } \\
\text { I and II } \\
\text { III non-manual } \\
\text { III manual } \\
\text { IV and V } \\
\text { Not employed }\end{array}$ & $\begin{array}{r}275 \\
327 \\
58 \\
214 \\
511\end{array}$ & $\begin{array}{r}-0.54 \\
-0.28 \\
0.25 \\
0.30 \\
0.31\end{array}$ & $\begin{array}{r}0.06 \\
-0.12 \\
-0.14 \\
-0.49 \\
0.26\end{array}$ & $3 \cdot 25$ & $<0.05$ \\
\hline
\end{tabular}

*Although NS at 0.05 level, included because of high correlation with parity.

years, and adult social class did so in conjunction with body mass index at age 26. There were no terms of interaction that added significantly to these statistical models.

Deviation values from these multivariate analyses were used to find the power of the independent variables and covariates in predicting body mass index at 36 years. Each individual was assigned a predicted body mass index according to his or her status on the appropriate variables-that is, dependent on sex-and the relation between actual and predicted body mass index was assessed. In particular, the percentage of individuals from the top decile of actual body mass index who were also in the top decile of predicted body mass index was calculated as a measure of sensitivity.

The sensitivity of prediction was poor when the index of relative weight at age 11 was used along with social factors, being $35.9 \%(52)$ for men and $43 \cdot 1 \%(62)$ for women. Better prediction figures were obtained for both sexes using body mass index at age 26 , but, even with additional demographic data, only $58 \cdot 7 \%$ (88) of men and $57 \cdot 0 \%(86)$ of women in the top decile were correctly predicted, leaving over $40 \%$ of people who were obese at age 36 who could not have been identified 10 years earlier.

\section{Discussion}

Findings from this study suggest that obesity at 36 years may usefully be considered as one of two types. Firstly, there was evidently a subgroup of individuals obese both in childhood (up to age 11) and in adult life. They formed a comparatively small percentage, $21 \cdot 4 \%$ (39), of the total population obese at age 36 years, $10.3 \%$ (8) of men and $29.8 \%$ (31) of women. The second subgroup comprised the remaining $78.6 \%$ (143) of obese 36 year olds, who first became obese in early adult life. This second subgroup was proportionately greater in men than in women-89.7\% (70) of men and $70.2 \%$ (73) of women were obese at 36 . In this study, therefore, childhood obesity was not the major contributor to obesity in 36 year old adults, and indeed those individuals who became obese between 11 and 36 were often not the most overweight in childhood.
The result, however, may indicate a long term effect of eating and exercise habits acquired in childhood or a willingness to adopt such habits in later life. There was a clear indication in men and women that later onset of obesity (between 26 and 36 years) was more common in the lower occupational groups and in those with lower educational qualifications.

Like all study populations this one is subject to cohort effect, particularly because children born in 1946 experienced postwar food rationing up to the age of 7 . In later cohorts an increasing prevalence of childhood obesity might be expected as a much wider range of food had become available; in fact, of children in the 1958 cohort of births ${ }^{30} 2 \%$ were obese at the age of 7 as compared with $0.8 \%$ in the 1946 cohort. In a consecutive series of 205 first born offspring of the 1946 cohort, who were measured at the age of 8 , $2.5 \%$ (5) were obese. A cohort of children born in 1970 and since followed up at 5 and 10 years should now be investigated for their prevalence of obesity. ${ }^{31}$

In view of the progressive nature of obesity documented here and the findings of increased mortality in men associated with obesity acquired in their $20 \mathrm{~s}, 3.5$ the crucial time for prevention appears to be early adulthood. Earlier assessment of body mass, even in conjunction with social indicators of risk, has poor sensitivity for the prediction of adult obesity. Intervention during childhood may be justifiable on other grounds, ${ }^{32}$ after giving due consideration to the "possible adverse effects of a screening programme." 33 Later effective intervention would require a programme of monitoring and this could be particularly important for men, who at present are less likely to encounter routine clinical examination than women. Even in early adulthood it would be unwise to restrict preventive methods to at risk groups as, on the evidence of this study, many of those who will become obese are not the most overweight and may fall within the range of normal weight. Health education, for children and adults, should be aimed at the development of 
nutritional and exercise habits with emphasis on long term objectives rather than short term weight reduction.

We thank those who made helpful comments on an earlier draft of this paper, especially Professor J R T Colley.

\section{References}

1 Royal College of Physicians. Obesity. $\mathcal{J}$ R Coll Physicians Lond 1983;17:3-58.

2 Garrow JS. Indices of adiposity. Nutrition Abstracts and Reviews in Clinical Nutrition-Series A 1983;53:697-708

3 Hubert HB, Feinleib M, McNamara PM, Castelli WP. Obesity as an independent risk factor for cardiovascular disease: a 26 year follow-up of participants in the Framingham Heart Study. Circulation 1983;67:968-77.

4 Rabkin SW, Mathewson FAL, Hsu PH. Relation of body weight to development of ischaemic heart disease in a cohort of young North American men after a 26 year observation period: the Manitoba Study. Am $\mathcal{F}$ Cardiol 1977;39:452-8.

5 Rhoads GG, Kagan A. The relation of coronary disease, stroke and mortality to weight in youth and middle age. Lancet 1983;i:492-5.

6 Pett LB, Ogilvie GF. The report on Canadian average weights, heights and skinfolds. Canadian Bulletin of Nutrition 1957;5:1-81.

7 Abraham S, Johnson CL, Najjar MF. Weight by height and age for adults 18-74 years: United States, 1971-74. Hyattsville, Maryland: National Center for Health Statistics, 1979. (DHEW publication No (PHS) 79-1656 Vital and health statistics; series 11 ; No 208.)

8 Bjelke E. Variation in height and weight in the Norwegian population. British fournal of Preventive and Social Medicine 1971;25:192-202.

$9 \mathrm{Knight}$ I. The heights and weights of adults in Great Britain. London: HMSO, 1984. (Office of Population Censuses and Surveys, Social Survey Division.)

10 Mullins AG. The prognosis in juvenile obesity. Arch Dis Child 1958;33:307-14

11 Abraham S, Nordsieck M. Relationship of excess weight in children and adults. Public Health Rep 1960;75:263-73

12 Miller FJW, Billewicz WZ, Thomson AM. Growth from birth to adult life of 442 Newcastle-uponTyne children. British foumal of Preventive and Social Medicine 1972;26:224-30.

13 Charney E, Goodman HC, McBride M, Lyon B, Pratt R. Childhood antecedants of adult obesity. N Engl I Med 1976;295:6-9.

14 Zack PM, Harlan WR, Leaverton PE, Cornoni-Huntley J. A longitudinal study of body fatness in childhood and adolescence. Journal of Pediatrics 1979;95:126-30.

15 Garn SM, Lavelle M. Two decade follow up of fatness in early childhood. Am 7 Dis Child 1985;139:181-5.
16 Abraham S, Collins G, Nordsieck M. Relationship of childhood weight status to morbidity in adults. HSMHA Health Report 1971;86:273-84.

7 Hawk LJ, Brook CGD. Influence of body fatness in childhood on fatness in adult life. Br Med 7 1979;i:151-2.

18 Stark O, Atkins E, Wolff $\mathrm{OH}$, Douglas JWB. A longitudinal study of obesity in the National Survey of Health and Development. BrMed $\mathcal{F}$ 1981;283:13-7.

$19 \mathrm{De}$ Wijn JF. Vetzucht bij kinderen. Deel II: de mogelijke relatie van vetzucht op de kinderleeftijd met vetzucht op oudere leeftijd. T Kindergeneesk 1981;49:208-13.

20 Atkins E, Cherry N, Douglas JWB, Kiernan KE, Wadsworth MEJ. The 1946 British birth cohort: an account of the origins, progress and results of the National Survey of Health and Development. In: Mednick SA, Baert AE, eds. Prospective longitudinal research; an empirical basis for the primany prevention of psychosocial disorders. Oxford: Oxford University Press, 1981:25-30.

21 Stewart AL. The reliability and validity of self reported weight and height. $\mathcal{J}$ Chronic Dis 1982;35:295-309.

22 Newens EM, Goldstein $\mathbf{H}$. Height, weight and the assessment of obesity in children. British Jourmal of Preventive and Social Medicine 1972;26:33-9.

23 Cole TJ. A method for assessing age-standardized weight-for-height in children seen crosssectionally. Ann Hum Biol 1979;6:249-68.

24 Ashwell M, Cole TJ, Dixon AK. Obesity: a new insight into the anthropometric classification of fat distribution shown by computed tomography. $\mathrm{BrMed} \mathcal{F}$ 1985;290:1692-4.

25 Durnin JVGN, Womersley J. Body fat assessed from total body density and its estimation from skinfold thickness measurements on 481 men and women aged 16-72 years. $\mathrm{Br} \mathcal{J}$ Nutr 1974;32:77-97.

26 Bray GA, ed. Obesity in America. Proceedings of the 2nd Fogarty International Centre conference on obesity. Washington: DHEW, 1979:1-19.

27 Douglas JWB, Ross JM, Simpson HR. All Our Future. London: Peter Davies, 1968.

28 Crisp AH, Douglas JWB, Ross JM, Stonehill E. Some developmental aspects of disorders of weight. Joumal of Psychosocial Research 1970;14:313-20.

29 Rona RJ, Morris RW. National Study of Health and Growth: social and family factors and overweight in English and Scottish parents. Ann Hum Biol 1982;9: 147-56.

30 Peckham CS, Stark O, Simonite V, Wolff $\mathrm{OH}$. Prevalence of obesity in British children born in 1946 and 1958. BrMed f 1983;286:1237-41.

31 Wadsworth MEJ, Peckham CS, Taylor B. The role of national longitudinal studies in the prediction of health, development and behavior. In: Walker DB, Richmond JB, eds. Monitoring child health in the United States: selected issues and policies. Cambridge, Massachusetts: Harvard University Press, 1984:63-85.

32 Somerville SM, Rona RJ, Chinn S. Obesity and respiratory symptoms in primary school. Arch Dis Child 1984;59:940-4.

33 Peckham C, Stark O, Moynihan C. Obesity in school children: Is there a case for screening? Public Health London 1985;99:3-9.

(Accepted 27 May 1986)

\title{
Influence of passive smoking on admissions for respiratory illness in early childhood
}

\author{
YUE CHEN, WANXIAN LI, SHUNZHANG YU
}

\begin{abstract}
An association was sought between passive smoking and inpatient admissions for respiratory illness in 1058 children born between 1 June and 31 December 1981 and living in the neighbourhoods of Nan-Jing Western Road and Yan-An Western Road in Jing-An District, Shanghai. The admission rate for first episodes of respiratory illness was positively correlated with the total daily cigarette consumption of family members during the children's first 18 months of life. The relative risk of developing a first episode of respiratory illness was 1.80 for children living in families including people who smoked 10 or more cigarettes a day compared with those living in non-smoking families. Multiple logistic regression analysis showed that the effect of passive smoking on inpatient admission for respiratory illness was independent of the child's birth weight, type of feeding, father's education, size of the home, and chronic respiratory disease among adults in the family. The adjusted odds ratios compared
\end{abstract}

\footnotetext{
Department of Epidemiology, School of Public Health, Shanghai Medical University, Shanghai 200032, People's Republic of China

YUE CHEN, MD, postgraduate student of public health

WANXIAN LI, MD, professor

SHUNZHANG YU, MD, professor

Correspondence to: Dr Yue Chen.
}

with the non-smoking group were $1 \cdot 17$ in families smoking 1-9 cigarettes daily and 1.89 in families smoking 10 or more cigarettes daily.

These data suggest that exposure to household cigarette smoke of children in early life increases the risk of severe respiratory illness.

\section{Introduction}

Cigarette smoking is one of the most important sources of air pollution in the home. ${ }^{12}$ As children in temperate zones are thought to spend most of their time indoors ${ }^{3}$ the potential hazards of indoor air pollution may be more important than those of outdoor air pollution. Many studies have reported that children exposed to parental cigarette smoking may have chronic cough, phlegm, and persistent wheeze and have higher risks of attacks of tonsillitis, pneumonia or bronchitis, and other respiratory illnesses. ${ }^{4-14}$ Harlap and Davies, in a prospective study of 10672 infants, found a dose response relation between the amount of maternal smoking and hospital admissions of infants for pneumonia and bronchitis. ${ }^{15}$ But it was argued that the mothers were reporting antenatal smoking instead of smoking during the first year of life, and paternal and other people's smoking was not considered. ${ }^{16}$ We present further evidence of an association between admission to hospital for respiratory illness and passive smoking in babies during the first 18 months of life without any maternal antenatal smoking effect. 